\title{
Gripopterygidae (Plecoptera) from Paranapiacaba mountains, southeastern Brazil
}

\author{
Pitágoras da Conceição Bispo ${ }^{1 *}$ and Lucas Silveira Lecci ${ }^{1,2}$ \\ ${ }^{1}$ Laboratório de Biologia Aquática, Departamento de Ciências Biológicas, FCLA, Universidade Estadual Paulista, Av. Dom \\ Antônio, 2100, CEP 19806-900, Assis, SP, Brazil \\ ${ }^{2}$ Laboratório de Entomologia Aquática, Departamento de Biologia, FFCLRP, Universidade de São Paulo, Av. dos Bandeirantes, \\ 3900, Monte Alegre, CEP 14040-901, Ribeirão Preto, SP, Brazil
}

Received 20 November 2010; Accepted 24 June 2011

\begin{abstract}
In the present paper, adults of the family Gripopterygidae collected in Paranapiacaba mountains are analyzed, the new species are described and a key to species of this family from this area is presented. Twenty one species in four genera of Gripopterygidae are recorded in Paranapiacaba mountains, São Paulo State, Brazil. Gripopteryx comprises six species: Gripopteryx cancellata, Gripopteryx reticulata, Gripopteryx garbei, Gripopteryx coruja, Gripopteryx pinima and Gripopteryx flinti. Paragripopteryx is represented by eight species: Paragripopteryx klapaleki, Paragripopteryx anga, Paragripopteryx blanda, Paragripopteryx egena, Paragripopteryx hamata and three new species: Paragripopteryx intervalensis, Paragripopteryx kapilei and Paragripopteryx paranapiacabae. Tupiperla is represented by six species: Tupiperla gracilis, Tupiperla tessellata, Tupiperla eleonorae, Tupiperla umbya and two new species, Tupiperla amandae and Tupiperla froehlichi. Guaranyperla is represented by only one species: Guaranyperla guapiara.
\end{abstract}

Key words: Stoneflies / aquatic insects / diversity / streams / mountains

\section{Introduction}

The family Gripopterygidae (Plecoptera) has an austral distribution and is the most diverse among the Antarctoperlaria with 277 species described in 50 genera (Fochetti and Tierno de Figueroa, 2008). The family occurs in Australia, New Zealand and in South America (Argentina, Bolivia, Brazil, Chile and Colombia) (Stark et al., 2009; Froehlich, 2010). Illies (1963) reviewed and described several genera and species of Gripopterygidae from South America. After Illies (1963), other papers were published (Froehlich, 1969; Benedetto, 1983; Vera, 2006a, b); however, the validity and boundaries of some genera need to be better defined. Recently, McLellan and Zwick (2007) described some genera and species, discussed some characters and presented a new key to South American nymphs. A wide evaluation of the family including the analysis of new characters and using a phylogenetic approach is necessary for the redefinition of some genera.
The gripopterygids known from Brazil are represented only by subfamily Gripopteryginae McLellan (McLellan, 1977) and are classified into four genera: Gripopteryx Pictet (Pictet, 1841; Froehlich, 1990, 1993; Lecci and Froehlich, 2011), Paragripopteryx Enderlein (Enderlein, 1909; Froehlich, 1969, 1994), Tupiperla Froehlich (Froehlich, 1969, 1998, 2002; Bispo and Froehlich, 2007) and Guaranyperla Froehlich (Froehlich, 2001). All of them occur in Paranapiacaba mountains, São Paulo State, Brazil.

The stonefly species from streams of Paranapiacaba mountains, mainly from Parque Estadual Intervales (PEI), have been described piecemeal since 1990 (Froehlich, 1994, 1996, 1998). Bispo and Froehlich (2004) analyzed the adults of Perlidae from PEI, discussed the characters of known species, described three new species and presented key to species from that region. In the present paper, adults of the other family of Plecoptera known from Brazil, Gripopterygidae, collected mainly in PEI and some few specimens collected in adjacent parks (PECB, Parque Estadual de Carlos Botelho and PETAR, Parque Turístico do Alto do Ribeira) of the Paranapiacaba mountains are analyzed; new species are described and a key to species of this family is presented.

*Corresponding author: pcbispo@gmail.com 

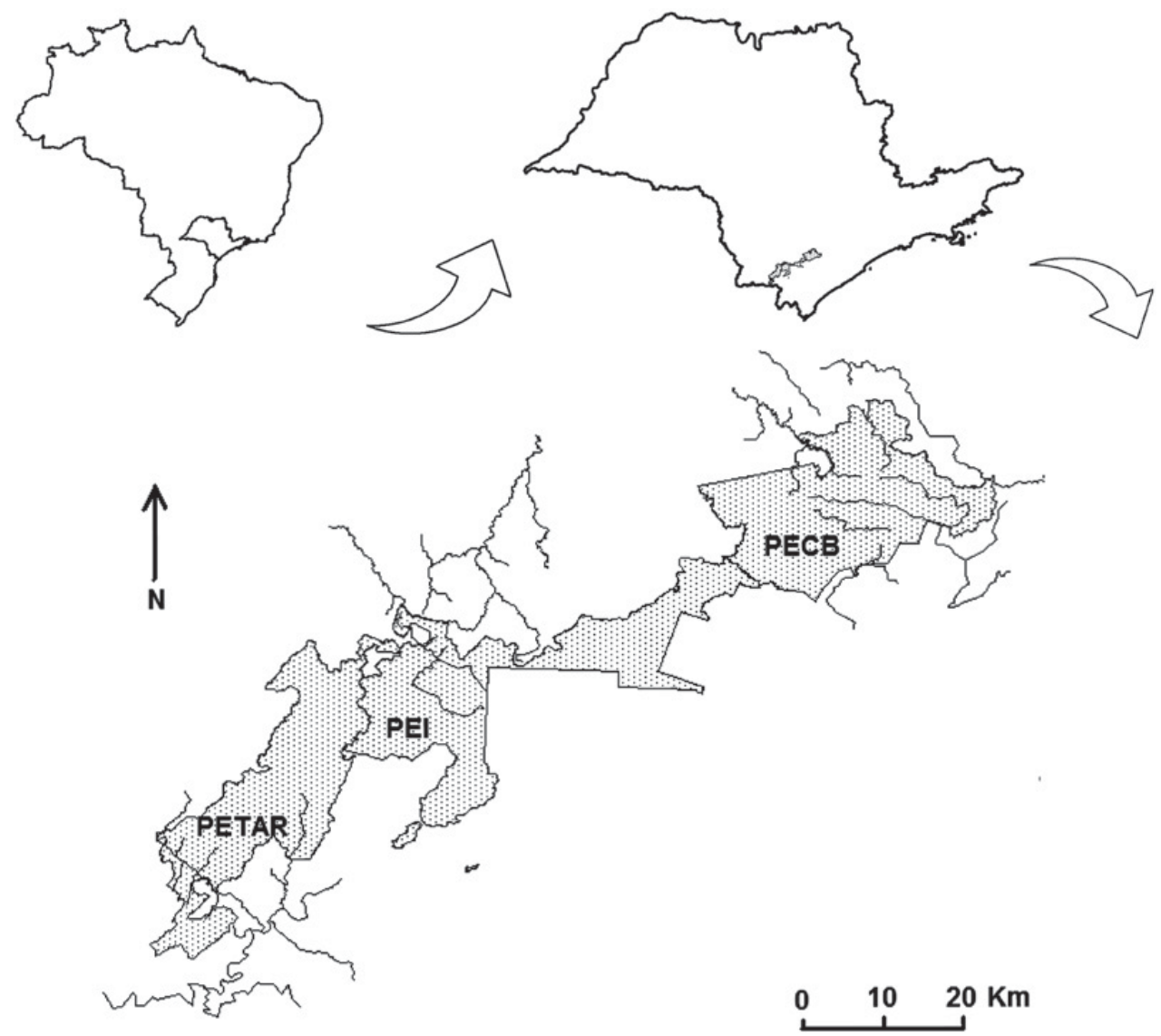

Fig. 1. Map of the three parks located in Paranapiacaba mountains, São Paulo State, Brazil. PECB (Parque Estadual Carlos Botelho), PEI (Parque Estadual Intervales) and PETAR (Parque Estadual Turístico do Alto do Ribeira).

\section{Material and methods}

The material was collected mainly in PEI. However, a few specimens from adjacent parks, PECB and PETAR were also analyzed. Those three parks are located in Paranapiacaba mountains (Fig. 1), south of São Paulo State, and represent one of the last well-preserved continuous areas of the Atlantic Rainforest. Most of the material was collected at night with lights, along low-order streams with rocky bottom. In PEI, most of the material was collected by the first author (PCB) and by Vera Lucia Crisci-Bispo. Most material of PECB and PETAR was collected by the first author and his students (Elisa Yokoyama, Gabriel de Paula Paciência and Igor Takebe). In those cases, no collector is indicated. Other collectors were Claudio Gilberto Froehlich (CGF), Adriano Sanches Melo (ASM), Cleber Macedo Polegatto (CMP), Henrique Paprocki (HP), Roberto Gama Alves (RGA) and Valdelânia Ribeiro de Ribeiro (VRR). The material is deposited in the Aquatic Insects Collection of the Aquatic Biology Laboratory (FCLA, State University of São Paulo) and the types in the Museum of Zoology (University of São Paulo). The research was based on adults; however, the occurrence of one species was based only on the immature stage.

\section{Results and discussion}

\section{Gripopteryx Pictet, 1841}

Capnia (Gripopteryx) Pictet, 1841, pp. 328-330.

Gripopteryx - Klapálek, 1904, p. 6; Illies, 1963, p. 152; Froehlich, 1990, p. 235; Stark et al., 2009, p. 85; Froehlich, 2010, p. 131; Lecci and Froehlich, 2011, p. 3.

Gripopteryx has 17 described species which are found in Uruguay, northeastern Argentina, Paraguay and south, southeastern, central Brazil and along the southern Brazilian coast (Froehlich, 1993) up to the south of the northeastern region (Lecci and Froehlich, 2011). The abdominal tergum $\mathrm{X}$ of male presents relatively long lateral clefts which separate partially the anterior part from a posterior triangular-shaped portion (Froehlich, 1990), with the tip bent downwards, except for Gripopteryx elisae Illies (Illies, 1963) and Gripopteryx flinti Froehlich (Froehlich, 1993), and with no projections (Lecci and Froehlich, 2011); paraproct long, curved upwards, compressed throughout its length and concave in its median to distal portion; apex of male epiproct short and relatively broad, with small row of teeth on its dorsal margin (Froehlich, 1990), except for Gripopteryx brasiliensis and Gripopteryx serrensis (epiproct absent); female paraproct with small apicodorsal projection, apex 
of female subgenital plate thickened (Lecci and Froehlich, 2011); eggs naked and dome-shaped (Froehlich, 1990); the nymphs have spines on the dorsal part of the abdomen (tergites 1-9); in tergum $X$, when present, the spine may be long, curved or straight (Froehlich, 1990).

\section{Gripopteryx cancellata (Pictet, 1841)} 330.

Capnia (Gripopteryx) cancellata Pictet, 1841, p. 328-

G. cancellata - Klapálek, 1904, p. 6; Jewett, 1960, p. 167; Illies, 1963, p. 152; Illies, 1966, p. 29; Zwick, 1972, p. 1129; Froehlich, 1990, p. 235; Froehlich, 2010, p. 132; Lecci and Froehlich, 2011, p. 3.

\section{Material}

Brazil, Iporanga, PEI, SP: 1 nymph, 19.XI.1992, CGF.

\section{Remarks}

G. cancellata is one of the species of the genus that have a wide distribution (south and southeastern Brazil) and all semaphoronts are described (Zwick, 1972; Froehlich, 1990, 1993). General colour of adults dark brown. No adults were collected in Paranapiacaba mountains. Adults from Campos do Jordão (also São Paulo State) have length of forewing 9.9-11.2 $\mathrm{mm}$ in males and 12.5$14.1 \mathrm{~mm}$ in females (Froehlich, 1990).

\section{Gripopteryx reticulata Brauer, 1866}

G. reticulata Brauer, 1866, p. 51; Jewett, 1960, p. 171; Illies, 1963, p. 157; Illies, 1966, p. 30; Froehlich, 1990, p. 238; Froehlich, 2010, p. 133; Lecci and Froehlich, 2011, p. 4.

\section{Material}

Brazil, Iporanga, PEI, SP: Ribeirão Água Comprida, 1 female, 26.VI.1999; 1 male, 15.VII.1999; 1 male, 27.X.1999; 1 female, 06.I.2000; Ribeirão do Carmo, 1 male, 08.XI.2000.

\section{Remarks}

G. reticulata is the largest species of the genus and occurs in mountainous areas from southeastern Brazil (Froehlich, 1990, 1993). Jewett (1960) and Froehlich (1990) presented illustrations, redescribed the adults and described the nymphs. General colour is dark brown. The specimens collected in PEI (length of forewing $13.8-14.7 \mathrm{~mm}$ in males and $17.5-18.6 \mathrm{~mm}$ in females) are smaller than those collected in Campos do Jordão (São Paulo State) (Froehlich, 1990).

\section{Gripopteryx garbei Navás, 1936}

G. garbei Navás, 1936, p. 731; Jewett, 1960, p. 170; Froehlich, 1990, p. 240; Froehlich, 1993, p. 22; Froehlich, 2010, p. 132; Lecci and Froehlich, 2011, p. 8.

Jewettoperla garbei - Illies, 1963, p. 185.

Paragripopteryx garbei - Illies, 1966, p. 45; Froehlich, 1969, p. 19.

\section{Material}

Brazil, Iporanga, PEI, SP: Ribeirão Água Comprida, 1 female, 15.VII.1999; 2 females, 6.I.2000; 1 female, 29.VI.2000; Ribeirão Bocaina, 1 female, 28.VI.2000; Ribeirão do Carmo, 1 female, 14.III.1999; 1 male, 3 females, 16.XII.1999; Ribeirão do Carmo (near Cachoeira das Pedrinhas), 1 male, 08.III.2004, ASM.

\section{Remarks}

G. garbei is a light brown to ochraceous species and was described based on material from Rio de Janeiro State (Navás, 1936). Adults and nymphs of G. garbei were redescribed and described, respectively, by Froehlich (1990). The species presents a wide distribution (south and southeastern Brazil). Recently, specimens were also collected in mountains from south of Bahia State (Camacan) (Lecci and Froehlich, 2011). The specimens collected in PEI (length of forewing 7.4-8.0 mm in male and $6.0-9.5 \mathrm{~mm}$ in female) are smaller than those collected in Campos do Jordão (São Paulo State) (Froehlich, 1990). The specimens from PEI present paraproct with the usual hooked apex. On the other hand, part of the specimens from PEI presents paraproct shorter and tergum $\mathrm{X}$ triangular with rounded apex. This variation will need a careful analysis, including both adults and nymphs from other areas to evaluate if they really belong to a single species.

\section{Gripopteryx coruja Froehlich, 1993}

G. coruja Froehlich, 1993, p. 25; Froehlich, 2010, p. 132; Lecci and Froehlich, 2011, p. 10.

\section{Material}

Brazil, Iporanga, PEI, SP: Ribeirão Três Córregos, 1 female, ASM, RGA.

\section{Remarks}

G. coruja was described based on males, females and nymphs collected mainly in the Estação Biológica de Boracéia (Salesópolis, São Paulo State) (Froehlich, 1993) and is recorded mainly in mountainous areas from north coastland of São Paulo State. The nymphs are very characteristic with four long spines on pronotum. The adults are brownish to ochraceous. Wing with usually 
1-2 pterostigmatic cross veins. Antennal base and leg with sparse long thin hairs. No males were collected in PEI. The female collected (length of forewing $12 \mathrm{~mm}$ ) is smaller than those collected in Estação Biológica de Boracéia (Froehlich, 1993).

\section{Gripopteryx pinima Froehlich, 1993}

G. pinima Froehlich, 1993, p. 29; Froehlich, 2010, p. 133; Lecci and Froehlich, 2011, p. 10.

\section{Material}

Brazil, Iporanga, PEI, SP: Ribeirão da Água Comprida, 1 male, 15.VII.1999; 1 male, 1 female, 27.X.1999.

\section{Remarks}

The adults and nymphs of $G$. pinima were described based on material collected in the Estação Biológica de Boracéia (Salesópolis) and Reserva Biológica do Alto da Serra de Paranapiacaba (Santo André) (Froehlich, 1993), both in São Paulo State. Recently, specimens of G. pinima were collected in Camacan (south of Bahia State, Brazil) (Lecci and Froehlich, 2011). G. pinima is a generally lightbrown species. The length of forewing of specimens from PEI is $13-14.2 \mathrm{~mm}$ in male and $15.7 \mathrm{~mm}$ in female, according to the size of specimens collected in other localities.

\section{Gripopteryx flinti Froehlich, 1993}

G. flinti Froehlich, 1993, p. 36; Froehlich, 2010, p. 132; Lecci and Froehlich, 2011, p. 11.

\section{Material}

Brazil, Iporanga, PEI, SP: 1 male, 6.VIII.1999, CGF; São Miguel Arcanjo, PECB: 1 male, 1 female, 11.X.2006.

\section{Remarks}

$G$. flinti was described based on specimens collected in Rio de Janeiro State (Nova Friburgo and Parque Estadual do Itatiaia) and in São Paulo State (Caraguatatuba). This species occurs in mountains from States of Minas Gerais, Rio de Janeiro and São Paulo. G. flinti is generally a darkbrown species and does not present a triangular tergum $\mathrm{X}$, like most of its congeners. The tergum X of $G$. flinti presents postero lateral expansions. The paraproct is long, with distal part strongly bent backward, apices thin and directed outward (Froehlich, 1993). The specimens collected in PEI (length of forewing $14.9 \mathrm{~mm}$ in male and $16.2 \mathrm{~mm}$ in female) are larger than those collected in other sites from Rio de Janeiro and São Paulo States (Lecci and Froehlich, 2011).

\section{Paragripopteryx Enderlein, 1909}

Paragripopteryx Enderlein, 1909, p. 416; Froehlich, 1969, p. 19; Froehlich, 1994, p. 227; Stark et al., 2009, p. 91; Froehlich, 2010, p. 135.

Jewettoperla - Illies, 1963, p. 184.

Paragripopteryx has 14 described species, 12 in Brazil (three described in this paper), and occurs in Uruguay, and along mountainous areas of south and southeastern Brazil. The nymphs present short legs without femoral spines and no abdominal dorsal spines. The adults can be confused with Gripopteryx; however, those of Paragripopteryx are smaller than most Gripopteryx species (Froehlich, 1990, 1994). The male adults present tergum $X$ with an extension that ends in two points or teeth; the laterodorsal clefts are small or inconspicuous; the epiproct is compressed, thin and with apical point directed forward; the eggs are flattened ellipsoid and have a cortical layer (Froehlich, 1969, 1990, 1994).

\section{Paragripopteryx klapaleki Enderlein, 1909}

P. klapaleki Enderlein, 1909, p. 416; Illies, 1966, p. 46; Froehlich, 1969, p. 19; Froehlich, 1994, p. 228; Froehlich, 2010, p. 136.

Gripopteryx klapaleki-Jewett, 1960, p. 170.

\section{Material}

Brazil, Iporanga, PEI, SP: 1 male, Ribeirão Caraça, 28.X.2002, ASM, RGA, PCB; 1 male, Ribeirão do Carmo, 30.X.2002; 1 male, Ribeirão Três Córregos, 02.XI.2002, ASM, RGA, PCB.

\section{Remarks}

P. klapaleki was described based on specimens collected in Rio de Janeiro State, Brazil. Froehlich (1969) presented illustrations and redescribed the species based on material from Reserva Biológica do Alto da Serra de Paranapiacaba (São Paulo State). P. klapaleki is a medium-sized species and is generally brownish to dark brown in colour. The species occurs in Serra do Mar and Serra da Mantiqueira, States of Rio de Janeiro and São Paulo (Froehlich, 1994). The length of forewing of males from PEI is $6.7-7.3 \mathrm{~mm}$, according to the size of specimens collected in Reserva Biológica do Alto da Serra de Paranapiacaba.

\section{Paragripopteryx anga Froehlich, 1969}

P. anga Froehlich, 1969, p. 23; Froehlich, 1994, p. 228; Froehlich, 2010, p. 135. 


\section{Material}

Brazil, Iporanga, PEI, SP: Ribeirão Cachoeira, 3 females, 8.XI.1993, CGF, HP; Córrego Roda D' Agua, 2 females, 12.XI. 1993, CGF, HP.

\section{Remarks}

$P$. anga was described based on material collected in Reserva Biológica do Alto da Serra de Paranapiacaba (Santo André, São Paulo State, Brazil) (Froehlich, 1969). Later, the distribution of that species was expanded to Estação Biológica de Boracéia (Salesópolis) (Froehlich, 1994) and in this paper to PEI, both in São Paulo State. $P$. ang $a$ is a generally brownish to ochraceous species. This species has an expansion of the tergum $X$, which differs it from other species of the genus (Froehlich, 1969). Paraproct is long with bristles. All semaphoronts are described (Froehlich, 1969). The length of forewing of females from PEI is $7.97-8.73 \mathrm{~mm}$, according to the size of specimens collected in Reserva Biológica do Alto da Serra de Paranapiacaba.

\section{Paragripopteryx blanda Froehlich, 1969}

P. blanda Froehlich, 1969, p. 26; Froehlich, 1994, p. 228; Froehlich, 2010, p. 135.

\section{Material}

Brazil, Iporanga, PEI, SP: 1 nymph, 17.II.1993; 1 female, 4.II.1993, CGF.

\section{Remarks}

$P$. blanda was described based on specimens collected in Reserva Biológica do Alto da Serra de Paranapiacaba (Santo André, São Paulo State) (Froehlich, 1969). Later, the distribution of this species was expanded to other areas within São Paulo State, Estação Biológica de Boracéia (Salesópolis) (Froehlich, 1994) and in this paper to PEI. The adults of P. blanda are generally dark brown, paraproct of male is robust in basal half and narrow towards apex to end in a sharp point (Froehlich, 1969). All semaphoronts are described. It was not possible to measure the female from PEI and no males were collected.

\section{Paragripopteryx hamata Froehlich, 1994}

P. hamata Froehlich, 1994, p. 234; Froehlich, 2010, p. 136.

\section{Material}

Brazil, Iporanga, PEI, SP: Ribeirão Bocaina, 1 female, 14.VII.1999; 1 female, 25.XI.1999; Chico Paes, 1 female, 31.X.2002, ASM, RGA, PCB.

\section{Remarks}

$P$. hamata was described based on specimens collected in Estação Biológica de Boracéia (Salesópolis, São Paulo State) (Froehlich, 1994). Herein, the distribution of that species is expanded to PEI. The colour of $P$. hamata ranges from light brown to ochraceous. Tergum $\mathrm{X}$ is dark, sclerotized, with lateral clefts and ending in a pair of small teeth (Froehlich, 1994). The length of forewing of females from PEI is 6.9-7.2 mm. The females from PEI are smaller than those collected in Estação Biológica de Boracéia.

\section{Paragripopteryx egena Froehlich, 1994}

P. egena Froehlich, 1994, p. 237; Froehlich, 2010, p. 136.

\section{Material}

Brazil, Iporanga, PEI, SP: 1 female, 15.VII.1999; 1 male; 1 female, 16.VII.1999. Ribeirão Bocaina, 5 males, 14.VII.1999.

\section{Remarks}

$P$. egena was described based on specimens collected in PEI (Froehlich, 1994). The general colour of this species ranges from brown to dark brown; it is one of the species of this genus in which the epiproct is absent; male paraproct is robust and narrowed distally (Froehlich, 1994). The length of forewing of specimens from PEI, including those analyzed by Froehlich (1994), is $6.3-6.8 \mathrm{~mm}$ in males and $6.7-8.1 \mathrm{~mm}$ in females.

\section{Paragripopteryx intervalensis, n. sp (Figs. 2-4)}

\section{Material}

Holotype. Brazil, Iporanga, PEI, SP: Chico Paes, 1 male, 31.X.2002, ASM, RGA, PCB.

\section{Description}

General colour brown. Head with frons and epicranial line dark brown. Pronotum brown with margins and rugosities darker. Wing and veins brown except for RA (dark brown); pterostigmatic cell in forewings with one cross vein. Leg brown, distal part of femur, tibia and tarsus darker.

Male. This species is described on the basis of a single male, with the following numerical data: width of head, $0.88 \mathrm{~mm}$; number of antennomeres, 35 ; length of forewing, $6.1 \mathrm{~mm}$; number of cercomeres, 16. Abdominal segments I-VII slightly membranous, with dorsal brown band on anterior half part of each abdominal segment. Abdominal segments VIII-X sclerotized. Sternum I-X and paraprocts hairy. Sternum IX forms a broad subgenital plate (Fig. 4). Tergum $X$ with an $M$-shaped small projection at apex (Fig. 2). Paraproct brown, simple, robust and wide 

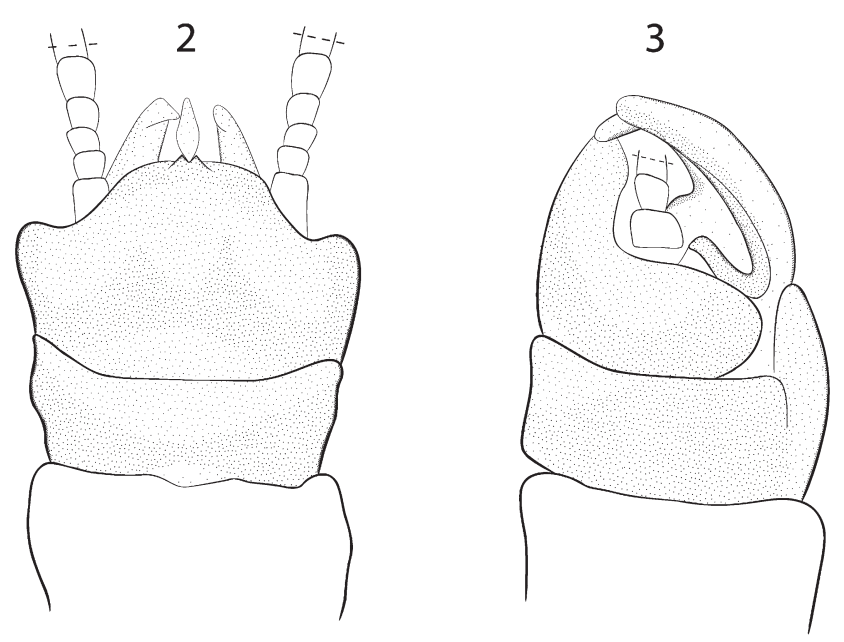

4
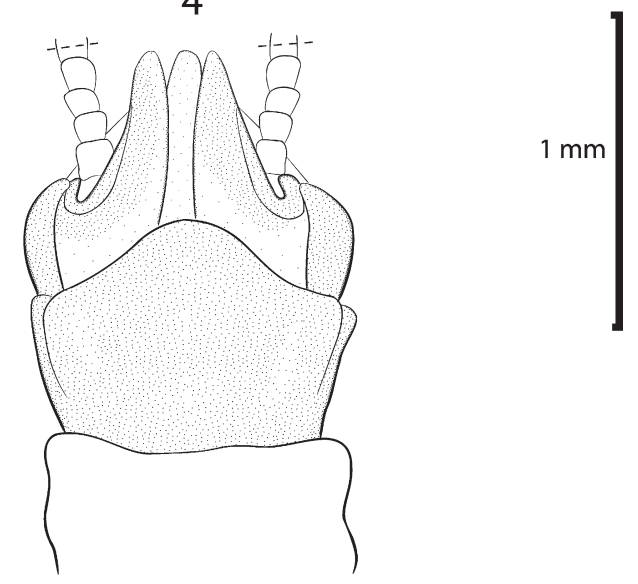

Figs. 2-4. Pragripopteryx intervalensis, n. sp. Holotype adult, male. Male terminalia in dorsal (2), lateral (3) and ventral views (4).

(Fig. 3). Epiproct simple, falciform, elongated and projected between paraprocts.

\section{Remarks}

$P$. intervalensis, n. sp. differs from its congeners by the combination of the following characters: paraproct simple, robust and wide; epiproct simple, falciform, elongated and projected between paraprocts.

\section{Etymology}

From Intervales, name of the park where the specimen was collected.

\section{Paragripopteryx kapilei, n. sp. (Figs. 5-7)}

\section{Material}

Holotype. Brazil, Iporanga, PEI, SP: Córrego Roda d'Água, 1 male, 02.II.2000, CGF, ASM, VRR, PCB.
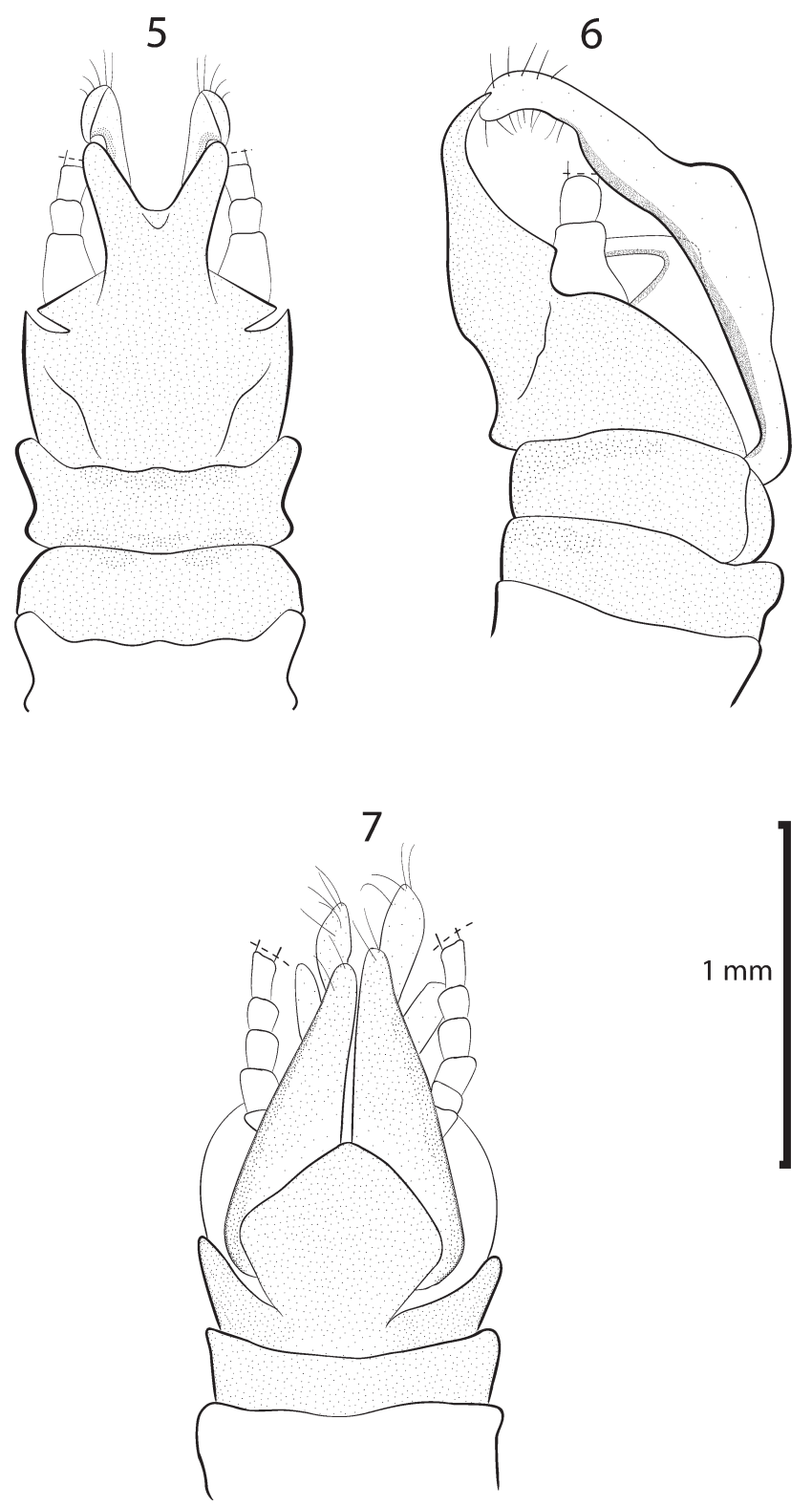

Figs. 5-7. Paragripopteryx kapilei, n. sp. Holotype adult, male. Male terminalia in dorsal (5), lateral (6) and ventral views (7).

Paratype: 1 male, córrego Roda d'Água, 10.V.2005, Mariano, R.

\section{Description}

General colour ochraceous to yellowish. Antenna ochraceous. Head with epicranial line pale brownish. Pronotum ochraceous, squarish with rounded corners; lateral parts darker and rugosities lighter. Wing pale ochraceous, veins ochraceous, RA darker; cross veins almost absent; pterostigmatic cell, in forewings, with one cross vein. Leg ochraceous. Cercus ochraceous.

Male. Numerical data $(n=2)$ : width of head, $0.98-1.02$ $\mathrm{mm}$; number of antennomeres, 45; length of forewing, 
$6.10 \mathrm{~mm}$; number of cercomeres, 14-16. Abdomen ochraceous to yellowish, with a dark band in posterior part of tergum (except tergum X). Sternum IX with subgenital plate hexagonal with rounded edges. Tergum $\mathrm{X}$ with a Y-shaped projection and with long lateral clefts (Fig. 5). Paraproct ochraceous, elongated, with stout setae in their distal part (Figs. 6 and 7). Epiproct simple, short and curved (Fig. 6). Cercus pale ochraceous.

\section{Remarks}

The terminalia of $P$. kapilei, n. sp. resembles that of $P$. ang $a$, but they can be differentiated by the size and shape of the epiproct, the lack of membrane on the paraproct of $P$. kapilei and by the shape of the projection of tergum X.

\section{Etymology}

The name honours Dr Fábio de Oliveira Roque (Kapile) for his contributions to the knowledge about diversity and ecology of aquatic insects from Brazil.

\section{Paragripopteryx paranapiacabae, n. sp. (Figs. 8-10)}

\section{Material}

Holotype. Brazil, Iporanga, PEI, SP: Lago Negro, 1 male 19.XI.1992, CGF. Paratypes: 2 males, Ribeirão do Carmo (near Cachoeira das Pedrinhas), 01.XI.2002, ASM. Iporanga, PETAR, SP: 1 male, 26-27.VIII.2001, Galati, E.

\section{Description}

General colour ochraceous. Pronotum with anterior and lateral borders darker. Wing pale yellowish, veins yellowish except for RA (yellow), no cross vein in pterostigmatic cell.

Male. Numerical data: width of head, 0.70-0.86 mm; number of antennomeres, 39-41; length of forewing, 6.0$6.4 \mathrm{~mm}$; number of cercomeres, 16-17. Abdominal segments equally sclerotized. Sternum IX forming a semicircular subgenital plate (Fig. 10). Extension of tergum X is elongated with a constriction on the basis (Fig. 8). Paraproct ochraceous, robust, bent backward and with a dorsal membrane (Fig. 9). Epiproct simple, short and hooked (Fig. 9).

\section{Remarks}

$P$. paranapiacabae, n. $\mathrm{sp}$. is distinguished from other species of the genus by the robust paraprocts with presence of a dorsal membrane and with extension of tergum $\mathrm{X}$ elongated with a constriction on the basis.

\section{Etymology}

From Paranapicaba mountains, region where the specimens were collected.
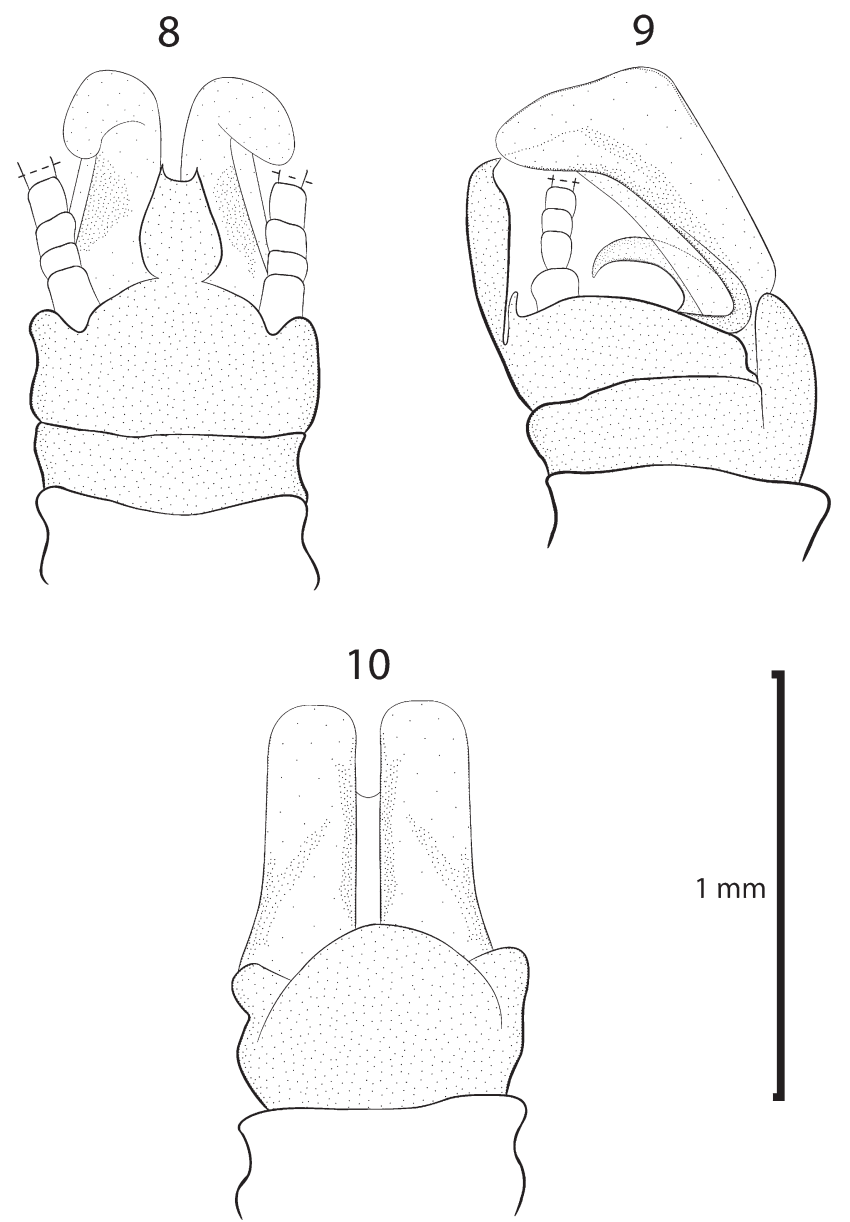

Figs. 8-10. Paragripopteryx paranapiacabae, n. sp. Holotype adult, male. Male terminalia in dorsal (8), lateral (9) and ventral views (10).

\section{Tupiperla Froehlich, 1969}

Tupiperla Froehlich, 1969, p. 28; Froehlich, 1998, p. 34; Bispo and Froehlich, 2007, p. 214; Froehlich, 2010, p. 137.

Tupiperla comprises 15 described species (Froehlich, 1998, 2002; Bispo and Froehlich, 2007), including the two described in this paper. Tupiperla has the following diagnostic characters: ventral spine on femur (Froehlich, 1969) (except in some specimens of T. jumirim Bispo and Froehlich, 2007); pronotum narrower than head; lack of pterostigmatic cross veins; in males, lack of a sclerotized epiproct, in addition to relatively long extension of tergum $\mathrm{X}$ ending in two separate teeth (Bispo and Froehlich, 2007). Tupiperla occurs in northeastern Argentina, Uruguay, Paraguay, southern, southeastern and mountainous areas of central and northeastern Brazil.

\section{Tupiperla gracilis (Burmeister, 1839)}

Semblis gracilis Burmeister, 1839, p. 876.

Paragripopteryx gracilis - Illies, 1963 (in part), p. 179. 
T. gracilis - Froehlich, 1969 (in part), p. 29; Zwick, 1972, p. 1131; Froehlich, 1998, p. 20; Froehlich, 2010, p. 138.

\section{Material}

Brazil, Iporanga, PEI, SP: Ribeirão Bocaina, 1 male, 1 female, 25.VI.1999; Córrego Lorena (Barra Grande), 1 female, 31.X.2002, ASM, RGA, PCB. São Miguel Arcanjo, PECB, SP: 1 male, Rio Taquaral, 09.IX.2006.

\section{Remarks}

T. gracilis occurs in Minas Gerais, Rio de Janeiro and São Paulo States and was redescribed by Froehlich (1998). This is a small- to medium-sized species, dark brown and has paraproct with apex strongly widened (Froehlich, 1998). The measured specimens collected in PEI (length of forewing $6.5 \mathrm{~mm}$ in male and in female) are smaller than those collected in other sites from Minas Gerais and São Paulo States (Froehlich, 1998).

\section{Tupiperla tessellata Brauer, 1866}

Gripopteryx tessellata Brauer, 1866, p. 51.

Gripopteryx neofriburgensis - Navás, 1916, p. 27; Jewett, 1960, p. 172.

T. tessellata - Froehlich, 1998, p. 21; Froehlich, 2010, p. 139.

\section{Material}

Brazil, Iporanga, PEI, SP, Ribeirão Água Comprida, 1 male, 09.III.2004, ASM.

\section{Remarks}

T. tessellata, known from the states of Rio de Janeiro, Minas Gerais and São Paulo, was redescribed by Froehlich (1998) and is a small- to medium-sized species with dark-brown colour and with a distinct forewing colour pattern (Froehlich 1998). The specimen collected in PEI is lighter in colour. According to Froehlich (1998), the morphometric characteristics vary for different populations. In PEI, the length of forewing is $7.1 \mathrm{~mm}$ in male.

\section{Tupiperla eleonorae (Froehlich, 1994) (Figs. 11-16)}

Paragripopteryx eleonorae Froehlich, 1994, p. 236.

T. eleonorae - Froehlich, 1998, p. 23; Froehlich, 2010, p. 138.

\section{Material}

Holotype. Brazil, Iporanga, Caverna Areias de Baixo, 1 male, 21.IX.1991, S. Homem, N. Moracchioli.

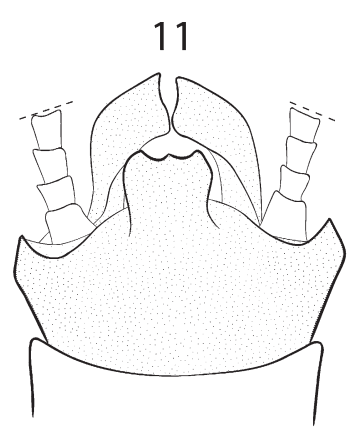

13
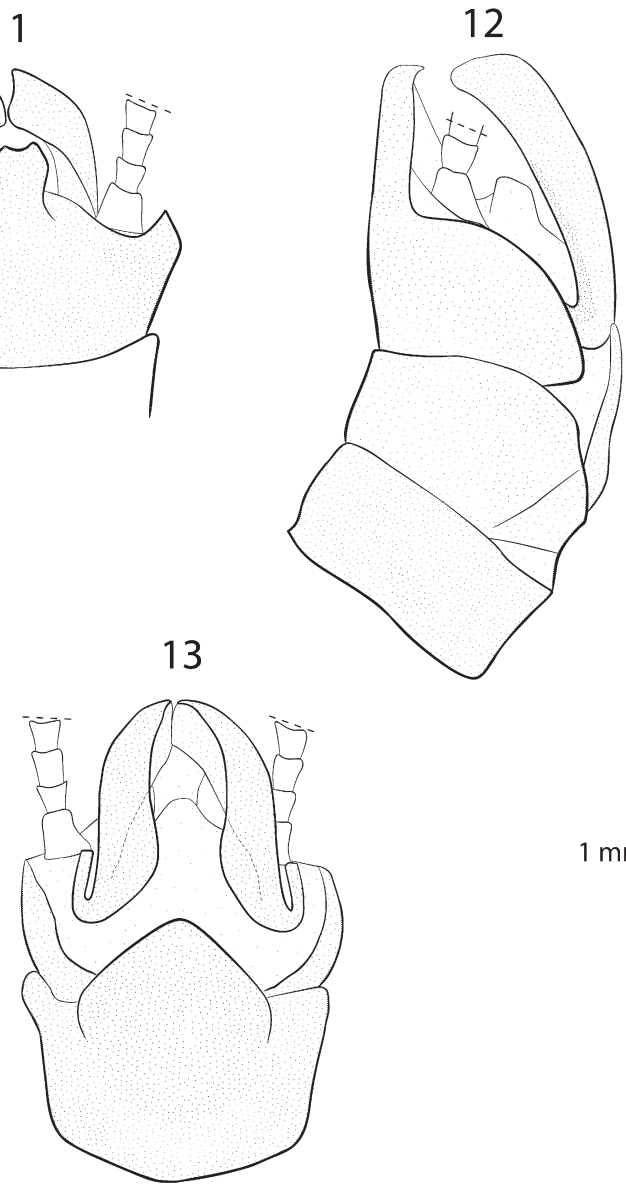

$1 \mathrm{~mm}$

Figs. 11-13. Tupiperla eleonorae Froehlich (1994). Adult, male. Male terminalia in dorsal (11), lateral (12) and ventral views (13).

Paratypes: 1 male, same data as holotype; 1 male, 6.1.1985, Trajano, E.

Additional material. Brazil, Iporanga, PEI, SP: 2 females, 12.I.1999; 2 females, 13.I.1999; 1 male, 16.I.1999; 17 males, 4 females, 8.I.2000. Ribeirão Água Comprida, 2 males, 15.VII.1999. Ribeirão do Carmo, 5 males, 15 males, 19 females, 16.VII.1999; 1 male, 4 females, 20.II.2000; 3 females, 25.III.2000; 1 male, 2 females, 30.X.2002, ASM, RGA, PCB.

\section{Remarks}

T. eleonorae was described by Froehlich (1994) as Paragripopteryx based on three specimens collected in Iporanga, São Paulo State. Froehlich (1998) analyzed additional material and considered that the original description was based on teneral specimens and transferred the species to Tupiperla. In this paper, the reanalysis of types and of additional material permitted us to conclude that there are two different species, both of the genus Tupiperla. Thus, the specimens collected and illustrated by Froehlich (1994) belong to T. eleonorae. On the other hand, the illustrations and part of material cited by Froehlich (1998) belong to a new species, 
14

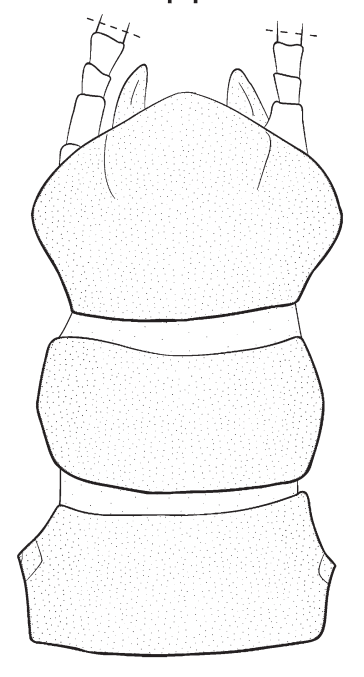

15

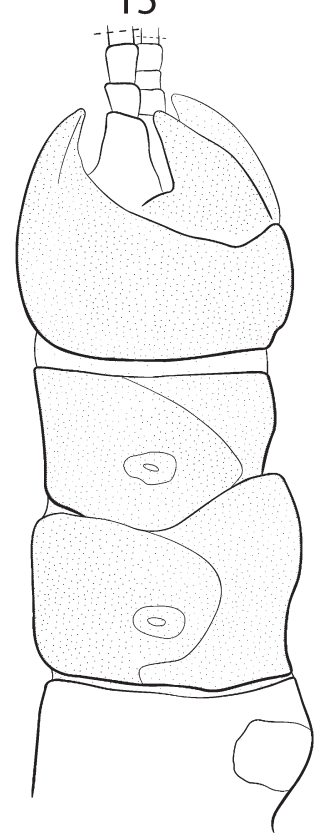

16

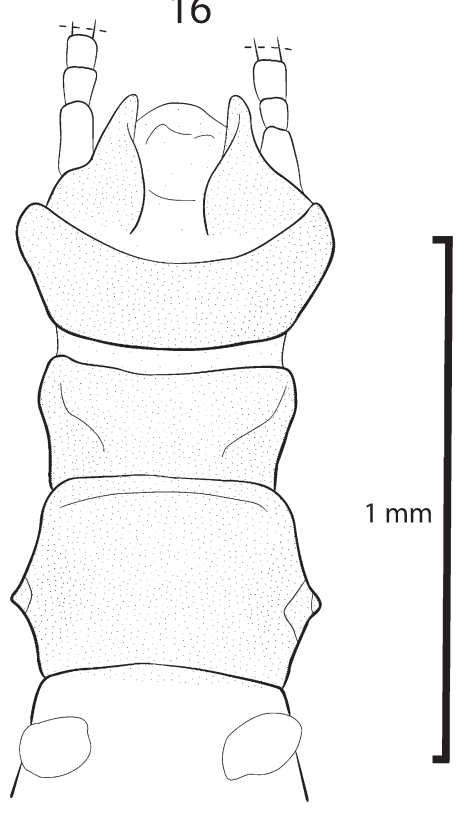

Figs. 14-16. Tupiperla eleonorae Froehlich (1994). Adult, female. Female adult, terminalia in ventral (14), dorsal (15) and ventrolateral views (16).

which is described in this paper (see Tupiperla amandae, n. sp.).

T. eleonorae is a small- to medium-sized species and is generally ochraceous. Antenna ochraceous with the lateral part of pedicel with darker band. Palpus ochraceous to brownish with apex of last segment with a little lighter spot. Lateral part of the head with a dark-brown band. Pronotum pale ochraceous with pleura with a brown band. Leg ochraceous to brownish with distal extremity of femur, distal and proximal extremities of tibia darker. Wing and veins pale ochraceous. The reticulated colour pattern of the wing, common in Tupiperla, is little evident. Cercus ochraceous.

Male. Morphometric characteristics: width of head, $0.78-0.98 \mathrm{~mm}(n=10$, mean $=0.95 \mathrm{~mm})$; number of antennomeres, 41-44 $(n=10$, mean $=42)$; length of forewing, 6.4-7 $\mathrm{mm}(n=10$, mean $=6.8 \mathrm{~mm})$; number of cercomeres, $12-14(n=10$, mean $=13)$. The male paraproct is simple and thin, apices rounded (Fig. 12). Lack of a sclerotized epiproct. Subgenital plate (Fig. 13) ochraceous. Extension of tergum $\mathrm{X}$ small (Fig. 11). Dorsal and ventral parts of abdomen from pale ochraceous to yellowish, lateral part brownish.

Female. Morphometric characteristics: width of head, 0.9-1.08 $(n=10$, mean $=1.03)$; number of antennomeres, 42-47 $(n=10$, mean $=44)$; length of forewing, 7-8.3 $(n=10$, mean $=7.9)$; number of cercomeres, 11-14 $(n=10$, mean $=13)$. The female has abdominal segments II-VII mostly membranous and with sclerotized spots in the sterna (Figs. 15 and 16). Lateral parts of the abdomen brownish. Subgenital plate ochraceous, posterior part almost straight (Fig. 16).

\section{Tupiperla umbya Froehlich, 1998}

T. umbya Froehlich, 1998, p. 31; Froehlich, 2010, p. 139.

\section{Material}

Brazil, Iporanga, PEI, SP: 2 females, 15.X.1999. Água Comprida, 3 males, 15.VII.1999; 1 male, 1 female, 27.X.1999; 1 male, 30.X.2002, ASM, RGA, PCB. Ribeirão Bocaina, 18 males, 17 females, 28.VI.2000.

\section{Remarks}

PEI is the locality where the type of $T$. umbya was collected (Froehlich, 1998). This species is generally brown in colour. The male paraproct broadens progressively towards the apex, has a subapical ventral posterior notch and apex twisted (Froehlich, 1998). The length of forewing of specimens from PEI is $6.9-8.0 \mathrm{~mm}$ in male and $8.5-9.8 \mathrm{~mm}$ in female, according to the size of type material (Froehlich, 1998).

\section{Tupiperla amandae, n. sp. (Fig. 17-21)}

\section{Material}

Holotype. Brazil, Ribeirão Grande, Fazenda Intervales (PEI), SP: 1 male, 19.XI.1992, CGF, CMP. Paratypes: Iporanga, PEI, SP, Ribeirão Água Comprida: 24 males, 22 females, 15.VII.1999; 23 males, 77 females, 06.I.2000; 


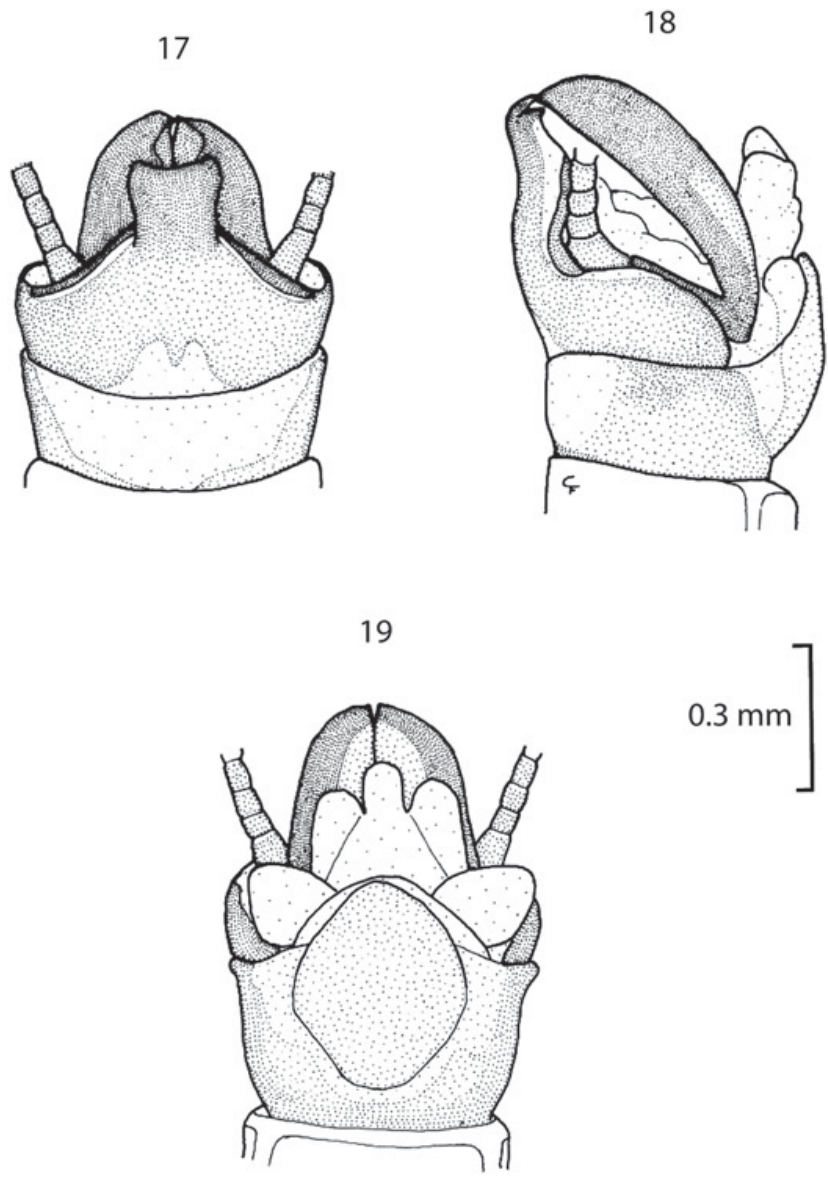

Figs. 17-19. Tupiperla amandae, n. sp. (modified from Froehlich, 1998): Holotype adult, male. Male terminalia in dorsal (17), lateral (18) and ventral views (19).

Ribeirão do Carmo; 11 males, 53 females, 16.VII.1999. Additional material: Iporanga, PEI, SP: 4 males, 24 females, 12.I.1999; 1 male, 2 females, 13.I.1999; 1 female, 15.I.1999; 5 males, 5 females, 16.I.1999; 4 males, 15 females, 16.VII.1999; 4 males, 2 females, 29.VI.2000. Ribeirão Água Comprida, 6 females, 23.VI.1999; 2 males, 5 females, 30.X.2002. Ribeirão Bocaina, 1 female, 14.VII.1999. Ribeirão do Carmo, 16 females, 24.VI.1999; 3 females, 19.VII.1999; 1 female, 28.X.1999; 1 male, 24 females, 20.II.2000; 1 male, 29 females, 25.III.2000; 4 females, 30.X.2002, ASM, RGA, PCB. Chico Paes, 1 male, 1 female, 31.X.2002, ASM, RGA, PCB. Córrego Roda d'Água, 3 males, 9 females, 14.I.1999. São Miguel Arcanjo, PECB, SP: 4 males and 2 females, Rio Taquaral, 09.IX.2006.

\section{Description}

T. amandae, n. sp. is a small-to-medium-sized species. General colour dark brown. Head brown with part posterior of clypeal area, anterior part of postfrontal suture and laterally to posterior ocelli lighter. Labrum light brown. Palpus brownish. Pronotum brown with darker rugosities. Leg brownish, distal extremity of femur
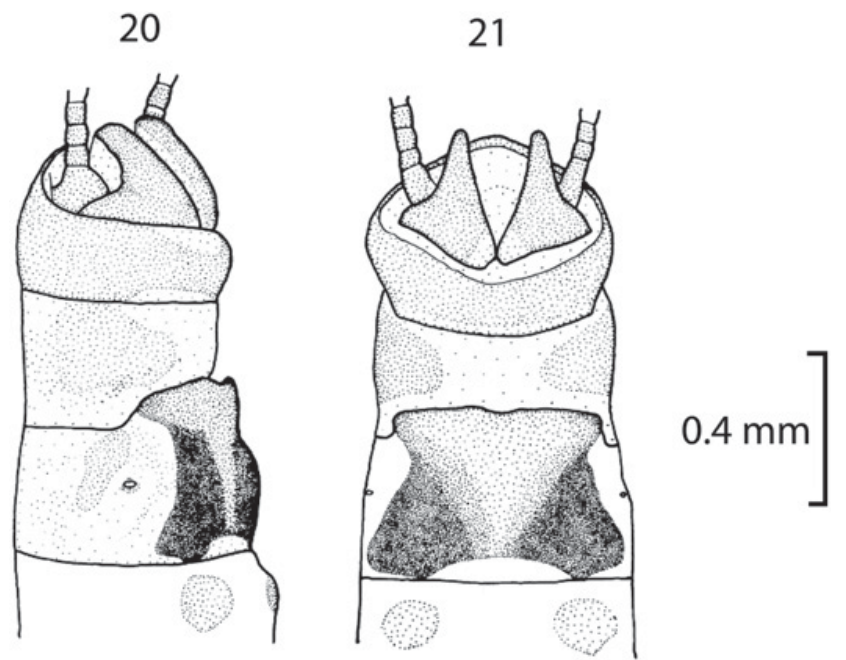

Figs. 20-21. Tupiperla amandae, n. sp. (modified from Froehlich, 1998): Paratype adult, female. Female adult, ventrolateral (20) and ventral views (21).

lighter with presence of two darker ventral bands, one of them extended throughout femur and another with different lengths. Tibia and tarsus brownish with darker ring in proximal part of tibia. Wing and veins brownish; the reticulated colour pattern, common in Tupiperla, is little evident. Cercus brownish.

Male. Morphometric characteristics: width of head, $0.78-0.98 \mathrm{~mm}(n=10$, mean $=0.92 \mathrm{~mm})$; number of antennomeres, 36-45 $(n=10$, mean $=41)$; length of forewing, 5.6-7.4 $\mathrm{mm}(n=10$, mean $=6.9 \mathrm{~mm})$; number of cercomeres, $11-15(n=10$, mean $=13)$. The male paraproct is simple, internally concave and strongly sclerotized (Figs. 18 and 19). Many examined males present the membranous penis at least in part everted between the subgenital plate and the paraprocts. Subgenital plate brownish, oval and more sclerotized in its central part (Fig. 19). Extension of tergum $\mathrm{X}$ short and simple (Fig. 17). Abdomen with most part of sterna yellowish, tergum $\mathrm{X}$ with anterior part yellowish and posterior brownish.

Female: Morphometric characteristics: width of head, $1.02-1.1 \mathrm{~mm}(n=10$, mean $=1.05 \mathrm{~mm})$; number of antennomeres, $40-45(n=10$, mean $=42)$; length of forewing, $8.2-8.7 \mathrm{~mm}(n=10$, mean $=8.5 \mathrm{~mm})$; number of cercomeres, $12-14(n=10$, mean $=13)$. The female has abdominal segments I-IX membranous, with sclerotized spots in the posterior part of sternum VII (Figs. 20 and 21). Subgenital plate brown, strongly sclerotized, with antero-lateral part darker, distal part squared, rounded corners and, in some specimens, with slight apical notch (Figs. 20 and 21).

\section{Remarks}

The male of $T$. amandae, n. sp. is morphologically similar to T. eleonorae; however, it is darker and does not have a conspicuous lateral brown band at head and pronotum. Besides, the females of the two species have 
22

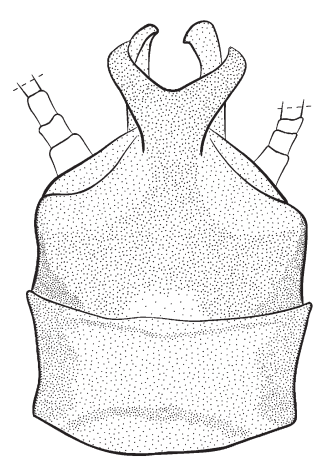

23

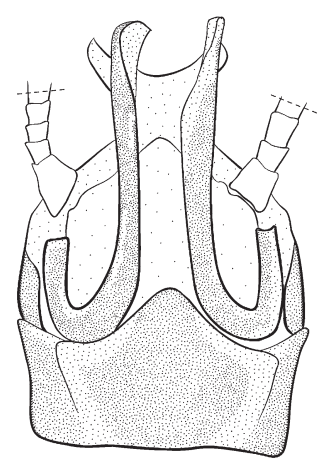

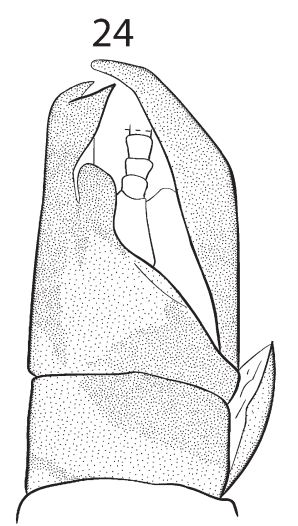

$1 \mathrm{~mm}$

Figs. 22-24. Tupiperla froehlichi, n. sp. Holotype adult, male. Male terminalia in dorsal (22), lateral (23) and ventral views (24).

totally different subgenital plates (see, T. eleonorae, Figs. 14-16; T. amandae, Figs. 20 and 21).

\section{Etymology}

The name is in memoriam of Amanda Lucas Gimeno, a laboratory fellow of the second author.

\section{Tupiperla froehlichi, n. sp. (Figs. 22-24)}

\section{Material}

Holotype. Brazil, Iporanga, PETAR, SP, Rio Betari: 1 male, 15.IX.2006.

\section{Description}

T. froehlichi is a medium-sized species. General colour dark brown. Head brown with region between ocelli darker. Maxillary palpus with the two first segments ochraceous and the two apical ones brownish. The apex of last segment of palpi with a small lighter spot. Pronotum brown with darker rugosities. Leg brownish, femur with distal extremity darker and with the presence of a ventral dark-brown band. Tibia and tarsus brownish with the presence of a darker ring in the proximal part of the tibia. Wing and veins brownish. Lack of pterostigmatic cross veins.

Male. The male presents the following morphometric characteristics: width of head, $1.12 \mathrm{~mm}$; number of antennomeres, 43; length of forewing, $8.4 \mathrm{~mm}$; number of cercomeres, 17. Paraproct long, up curved, slightly concave, sclerotized and with pointed apex (Fig. 24). Subgenital plate hexagonal with rounded corners (Fig. 23), ochraceous to brownish, the central part being darker. Extension of tergum $\mathrm{X}$ large and $\mathrm{Y}$ shaped (Fig. 22). Abdomen brownish to ochraceous. Tergum $\mathrm{X}$ dark brown, with middle of anterior part yellowish.

\section{Remarks}

T. froehlichi, n. sp. differs from other species of the genus by the combination of the following characters: extension of tergum $\mathrm{X}$ large and forming a open $\mathrm{Y}$, paraproct long, slightly concave, sclerotized and pointed apically.

\section{Etymology}

We are pleased to name this species in honour of Dr Claudio G. Froehlich in recognition of his many contributions to the knowledge about aquatic insects, especially Brazilian Plecoptera.

\section{Guaranyperla Froehlich (2001)}

Guaranyperla Froehlich (2001), p. 377; Stark et al. (2009), p. 87; Froehlich (2010): 134.

Guaranyperla comprises three species and occurs in mountainous areas of southeastern Brazil. The nymphs present thoracic segments with broad paranota and body covered by vesicular hairs. In adults, pronotum relatively broad with anterior corners little projected; leg with femoral spine (also in nymphs) and pterostigmatic crossveins present (Froehlich, 2001). Male genitalia without epiproct and extension of tergum $\mathrm{X}$ short and ending in two teeth (Froehlich, 2001).

\section{Guaranyperla guapiara Froehlich, 2001}

G. guapiara Froehlich, 2001, p. 378; Froehlich, 2010, p. 134.

\section{Material}

Brazil, Iporanga, PEI, SP: Rio das Mortes, 4 females, 6.VIII.1997, CGF, ASM, VRR.

\section{Remarks}

G. guapiara was described by Froehlich (2001) based on females and nymphs from PEI. The general colour 
of the species is dark brown. Length forewing of female $10.3-11.9 \mathrm{~mm}$.

\section{Key to male adults of Gripopterygidae from Paranapiacaba} mountains

1. Femoral spines absent $\ldots \ldots \ldots \ldots \ldots \ldots$

1'. Femoral spines present. . . . . . . . . . 3

2. Male adults with tergum $X$ ending in a rounded or pointed apex. Epiproct short and broad with a row of small teeth around the anterodorsal

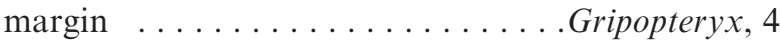

2'. Male adults with tergum $X$ always ending in two points or teeth. Epiproct generally compressed, thin and ending in an apical point directed forward ........... Paragripopteryx, 9

3. Pronotum relatively broad with anterior corners little projected, pterostigmatic crossveins present; extension of tergum $\mathrm{X}$ of males short. ....... G. guapiara

3'. Pronotum narrower than head; pterostigmatic cross veins absent; extension of tergum $\mathrm{X}$ of males long ................... Tupiperla, 15

4. Posterior part of tergum $\mathrm{X}$ with posterolateral expansions ................... flinti

4 '. Posterior part of tergum $\mathrm{X}$ resembling a triangle with a rounded apex .............. 5

5. Paraprocts with apex hooked . . . . . . . 6

5'. Paraprocts with apex rounded .......... 7

6. Smaller species, length of forewing 7-10 mm, with a pale colouration .................. garbei

6'. Larger species, length of forewing larger than $13.5 \mathrm{~mm}$, with a dark-brown colouration. . . . . . . . .................... . reticulate

7. Subgenital plate with shallow apical notch....... ....................... . . pinima

7'. Subgenital plate without shallow apical notch . . .8

8. Wing membrane homogeneously dark-brown ..... ........................ cancellata

8'. Forewing membrane pale brown with irregularly strewn brown spots . . . . . . . . . . . . coruja

9. Sclerotized epiproct absent. . . . . . . . P. egena

9'. Sclerotized epiproct present . . . . . . . . . . . 10

10. Lateral clefts in tergum $X$ present . . . . . . . . 11

10'. Lateral clefts in tergum $X$ absent . . . . . . . . . . . 12

11. Process of tergum $\mathrm{X}$ short .......... . hamata

11'. Process of tergum $\mathrm{X}$ long and $\mathrm{Y}$-shaped ........ $\ldots \ldots \ldots \ldots \ldots \ldots \ldots$. . . kapilei, n. sp.

12. Process of tergum $\mathrm{X}$ with a constriction on the basis..................... . 13

12 '. Process of tergum $X$ without basal constriction . . 14

13. In lateral view paraproct broadened apically ...... ............. P. paranapiacabae, n. sp.

13'. In lateral view paraproct acuminated at apex. . . . . $\ldots \ldots \ldots \ldots \ldots \ldots$. . . . . . . . . . . . . . . . . anda

14. Process of tergum $\mathrm{X}$ spatulate ......... . anga

14 '. Process of tergum $X$ with a small M-shaped projection. . . . . . . . . P. intervalensis, n. sp.

15. Paraprocts much broadened apically . . . . . . . 16
15'. Paraprocts only moderately or not at all broadened towards apex ................ . . 17

16. Apical broadened part of paraprocts rounded and often twisted ............... . gracilis

16'. Paraprocts apices truncated, often bent ventrally...

T. umbya

17. Paraprocts thin with almost parallel margins; apices curving upwards. ............ tessellate

17 '. Paraprocts either broadening gradually towards apex or relatively thick . . . . . . . . . . . . . 18

18. Tergum X process $\mathrm{Y}$-shaped ... T. froehlichi, n. sp.

18'. Tergum $X$ process not as above . . . . . . . . . . 19

19. Yellowish to ochraceous species with lateral part of head and pleura of pronotum with brown band................. T. eleonorae

19'. Dark species, head and pronotum without conspicuous lateral brown band .......T. amandae, n. sp.

Acknowledgements. We thank Dr Claudio G. Froehlich for lending some specimens and for several suggestions on the manuscript. PCB thanks FAPESP (State of São Paulo Research Foundation, numbers 98/11074-3; 02/07216-4 and 04/09711-8) and CNPq (National Council for Scientific and Technological Development, numbers 473246/2004-0 and 477349/2007-2) for constant support. PCB thanks CNPq (number 301652/2008-2) and LSL thanks CAPES (Coordination for the Improvement of Higher Education Personnel) for fellowships. We also thank Vera Lucia Crisci Bispo, field guide João da Cruz, driver Antonio Marcio Zanetti and students Elisa Yokoyama, Gabriel de Paula Paciência and Igor Takebe for help in field work. We thank José A. Rafael (INPA) for lending G. garbei and G. pinima specimens from Northeast of Brazil and Elisa Yokoyama for drawing the map. Part of this work was also supported by the FAPESP within the Program BIOTA (The Biodiversity Virtual Institute Program, http://www.biota.org.br, number 1998/05073-4).

\section{References}

Benedetto L., 1983. Plecopteros del Uruguay I: Paragripopteryx baratinii, n. sp. Stud. Neotrop. Fauna Environ., 18, 19-23.

Bispo P.C. and Froehlich C.G., 2004. Perlidae (Plecoptera) from Intervales State Park, São Paulo State, southeastern Brazil. Aquat. Insects, 26, 97-114.

Bispo P.C. and Froehlich C.G., 2007. Stoneflies (Plecoptera) from northern Goiás State, central Brazil: new record of Kempnyia oliveirai (Perlidae) and a new species of Tupiperla (Gripopterygidae). Aquat. Insects, 29, 213-217.

Brauer F., 1866. Familie Perlidae. 51-52. In: Neuropteren. Reise der Österreichischen Fregatte Novara um die Erde in den Jahren 1857, 1858, 1859 unter den Befehlen des Commodore B. von Wüllerstorf-Urbair. Aus der Kaiserlich-Königlichen Hof- und Staatsdruckerei in Commission bei K. Gerold's Sohn, Vienna. Zoologischer Theil, 2, Band (1: A), 4, 1-105.

Burmeister H., 1839. Handbuch der Entomologie. Plecoptera, 2, 863-881.

Enderlein G., 1909. Klassification der Plecopteren sowie Diagnosen neuer Gattungen und Arten. Zool. Anz., 34, 385-419. 
Fochetti R. and Tierno de Figueroa J.M., 2008. Global diversity of stoneflies (Plecoptera; Insecta) in freshwater. Hydrobiologia, 595, 365-377.

Froehlich C.G., 1969. Studies on Brazilian Plecoptera 1. Some Gripopterygidae from the Biological Station at Paranapiacaba, State of São Paulo. Beitr. Neotrop. Fauna, 6, 17-39.

Froehlich C.G., 1990. Brazilian Plecoptera 6. Gripopteryx from Campos do Jordão, State of São Paulo (Gripopterygidae). Stud. Neotrop. Fauna Environ., 25, 235-237.

Froehlich C.G., 1993. Brazilian Plecoptera 7. Old and new species of Gripopteryx (Gripopterygidae). Aquat. Insects, 15, 21-28.

Froehlich C.G., 1994. Brazilian Plecoptera 8. On Paragripopteryx (Gripopterygidae). Aquat. Insects, 16, 227-239.

Froehlich C.G., 1996. Two new species of Kempnyia from southern Brazil Plecoptera: Perlidae). Mitt. Schweiz. Entomol. Gesellschaft, 69, 117-120.

Froehlich C.G., 1998. Seven new species of Tupiperla (Plecoptera: Gripopterygidae) from Brazil, with a revision of the genus. Stud. Neotrop. Fauna Environ., 33, 19-36.

Froehlich C.G., 2001. Guaranyperla, a new genus in the Gripopterygidae (Plecoptera). In: Domínguez E. (ed.), Trends in research in ephemeroptera and plecoptera, Kluwer Academic/Plenum Publisher, New York, $377-$ 383.

Froehlich C.G., 2002. Two new species of Tupiperla (Plecoptera: Gripopterygidae) from the Missions area of Argentina and Paraguay. Aquat. Insects, 24, 37-40.

Froehlich C.G., 2010. Catalogue of Neotropical Plecoptera. Illiesia, 6, 118-205.

Illies J., 1963. Revision der südamerikanischen Gripopterygidae (Plecoptera). Mitt. Schweiz. Entomol. Ges., 36, 145-248.

Illies J., 1966. Katalog der rezenten Plecoptera. Das Tierreich 82, Walter de Gruyter and Co, Berlin. xxx $+632 p$.
Jewett S., 1960. Notes and descriptions concerning Brazilian stoneflies. Arq. Mus. Nac., 50, 167-184.

Klapálek F., 1904. Plecopteren. Hamb. Magalh. Sammel., 7, 2-13.

Lecci L.S. and Froehlich G.G., 2011. Taxonomic revision of Gripopteryx (Pictet, 1841) (Plecoptera: Gripopterygidae). Zootaxa, 2792, 1-21.

McLellan I.D., 1977. New alpine and southern Plecoptera from New Zealand, and a new classification of the Gripopterygidae. N. Z. J. Zool., 4, 119-147.

McLellan I.D. and Zwick P., 2007. New species of and keys to South American Gripopterygidae (Plecoptera). Illiesia, 3, $20-42$.

Navás L., 1916. Fam. Pérlidos, pp. 26-28. In: Neurópteros sudamericanos. Brotéria, Sér. Zool., 14, 14-35.

Navás L., 1936. Neuropteros sudamericanos. Brotéria (Sér. Zool.), 14, 26-28.

Pictet F., 1841. Histoire Naturelle Générale et Particulière des Insects Névroptères. Famille des Perlides, $1^{\text {ère }}$ Partie: 1-423. Kessmann, Genève.

Stark B.P., Froehlich C.G. and Zúñiga M.C., 2009. South American Stoneflies (Plecoptera). In: Adis J., Arias J., Golovatch S., Wantzen M. and Rueda-Delgado G. (eds.), Aquatic biodiversity in Latin America, Vol. 5. Pensoft Sofia, Moscow, 154 pp.

Vera A., 2006a. Rediscovery of Neopentura semifusca (Plecoptera: Gripopterygidae), description of the male imago, redescription of the female and the nymph. Rev. Soc. Entomol. Argent., 65, 69-77.

Vera A., 2006b. A new species of Teutoperla Illies, 1963 from Chile: Teutoperla maulina n. sp. (Plecoptera, Gripopterygidae), with comments about its biology. Acta Entomol. Chilena, 30, 29-38.

Zwick P., 1972. Die Plecopteren Pictets und Burmeisters, mit Angaben über weitere Arten (Insecta). Rev. Suisse Zool., 78, 1123-1194. 